Bengal Medical Establishment. - To be Brigade Surgeons: Surgeons-Major Alfred James Dale, Benjamin Simpson, M.D., Robert Faure Hutchinson, M.D., John Picthall, M.D., George Vernon Currie, Theobald Ringer, M.D., Philip Warren Sutherland, Alfred Eteson, M.D., William Watson, Alexander John Cowie, William John Palmer, M.D. (since retired), James Henry Loch, M.D., Robert Rouse, James Rawlinson Jackson, M.D., Archibald Macdonald Garden (since retired), John Brake, Alexander Garden, William Walker, M.D., George Alder Watson, Theobald Mathew, James Fairweather, M.D., Charles Julian Jackson, Robert Bird, M.D., and John Martin Coates, M.D.

Bombay Medical Establishment.-To be Brigade Surgeons: Surgeons-Major Lewis Stanhope Bruce, William Peyton Partridge, Henry Cook, M.D., John Pinkerton, M.D., Christopher Joynt, M.D., William Edward Cates, John Cruickshank, M.D., Charles Kelway Colston, and William Henry Colville.

ADMIRALTY. - The following appointments have been made:-Staff Surgeon J. D'A. Hervey to the Sappho, when commissioned on the 16th; Surgeon Wm. R. White to the Royal Adelaide.

Brigade Surgeon William Langford Farmar and SurgeonMajor T. W. Jackson, Army Medical Department, have arrived home from India on six months' leave of absence on private affairs.

The last mails from the West Indies brought intelligence that some cases of yellow fever had occurred at Barbadoes amongst the civil population, and that precautions have been taken by the military and medical authorities to prevent, if possible, the disease spreading to the garrison.

\section{MEDICAL NOTES IN PARLIAMENT.}

\section{Small-pox Hospital Ships.}

In the House of Commons on Monday Mr. Dodson replied to Baron H. de Worms that he could not admit that the small-pox hospital ships off Greenwich were moored so close to the shore that there was danger of their causing the epidemic to spread to the adjoining districts. He was distinctly advised by one of the medical inspectors, who had great experience, that no such risk was to be apprehended. No direct notice was given to the owners of the wharves in front of which the ships were moored, but the intention to place them there was publicly known some time beforehand, and no objection was raised. So far from the Thames Conservancy having objected, the spot was selected at their suggestion. The Asylums Board at first proposed to place the vessels lower down the river, but the Local Government Board were advised that acute cases could not, without serious danger, be removed to so great a distance. The ships were now moored close to the spot where the Dreadnought was formerly stationed. They were intended to remain only as long as the epidemic lasted. He could not state the distance from the shore, but he had been on board the ships himself.

\section{Small-pox Statistics.}

On Tuesday Mr. Dodson stated to Mr. H. Allen that the Registrar-General's returns showed, as far as practicable, the actual number of deaths from small-pox amongst vaccinated and unvaccinated persons in the metropolis. He had no means of ascertaining the number of cases of the disease which occurred, except those treated in the hospitals. Statistics on that subject would shortly be laid before the House.

Vaccination in the French Army.

Mr. Dodson, in answer to Mr. Blennerhassett, said he had received an extract from a French newspaper, stating that four regiments of Zouaves at Algiers were afflicted with disease in consequence of vaccination. He would consider whether it was desirable to address a communication to the French Government on the subject.

\section{Emigrant Ships.}

Mr. Chamberlain, answering a question by Mr. Talbot, stated that Miss O'Brien's complaints as to the treatmen tof emigrants on board the Atlantic steamers had been disproved by the Board of Trade inquiry. Copies of the report had been sent to the shipowners, with a circular inviting communications from them, and there was no reason to doubt that they would adopt proper precautions.

The Limerick Poisoning Case.

On Wednesday Mr. Gibson gave notice that on Friday he would ask the Chief Secretary to the Lord Lieutenant of Ireland whether his attention had been called to the recent lamentable death by poisoning of Mr. Hone in Limerick, and whether he would take steps to have a thorough and satis. factory investigation into the occurrence.

\section{A Publican as Registrar.}

On Wednesday Mr. Forster stated to Mr. Biggar that the appointment of Robert Humphrey, a Belfast publican, as deputy registrar of births, marriages and deaths, in the dis. tricts of Dr. Martin and Dr. Torrens, was the subject of investigation by a Government inspector. The result of the inquiry was not yet known.-Mr. Biggar gave notice of another question for Monday.

\section{ROYAL COLLEGE OF SURGEONS OF ENGLAND.}

AT an ordinary meeting of the Council of the Royal College of Surgeons of England, held on Thursday last, the resignation of Mr. John Marshall, F.R.S., from the Court of Examiners, was accepted. The vacancy thus caused will be filled at the meeting of the Council to be held in October next. No nominations have yet been made.

\section{"A DISCLATMER."}

\section{To the Editor of THE LANCET.}

SIR,-My name having been printed in the programme of the International Medical Congress for Monday last, in connexion with a proposed demonstration of "Hypnotism" by Dr. Beard of New York, I beg permission to state that I have never witnessed any of Dr. Beard's experiments ; and had a paper of mine, which was accepted by the Mental Section, been read as arranged on Monday afternoon, I intended to enter a protest against the assumption that in introducing the subject I introduced Dr. Beard. The form in which the announcement was made was obviously wrong. I had no "remarks" to make upon Dr. Beard's demonstra. tions, being wholly ignorant of their nature or purpose.

Will you allow me further to say, that so far am I from having any sympathy with "mesmerism," "magnetism," or "spiritualism," that I have never been present at any séance of the class, or witnessed any experiments, in which the results obtained were not distinctly due to the operation of physical forces acting in physical processes. I have no belief in any form of biological phenomena which cannot be explained on purely physiological grounds and premisses. The paper which I proposed to read, and which in my absence was "taken as read," and will, therefore, be printed in the Transactions, explains what is called "Hypnotism"while objecting to the term-on the commonly received principles of nervous action.

$$
\text { I am, Sir, yours truly, }
$$

Welbeck-street, w., Aug. 8, 1881. J. MoRTrMer GraNvilLE.

North of Scotland Medical Association.At the annual meeting of this Association, held at Aberdeen last week, Dr. Lyon of Peterculter was installed as the new president, in place of Dr. Beveridge, who retired. Dr. Lyon's address dealt with the present as compared with past methods of combating certain forms of disease. The question of the notification of infectious diseases was introduced by attention being drawn to a Bill submitted by Mr. Webster, M.P. which was regarded with approval by the members. A motion expressive of the desire of the Association to cooperate with other scientific bodies in an invitation to the British Association to meet next year at Aberdeen was agreed to. Dr. Pirrie, Professor of Surgery, was nominated as the President elect. 